\title{
Changemaking and English Language Learners (Els): Language, Content and Skill Development through Experiential Education
}

\author{
Viviana Alexandrowicz ${ }^{1}$ \\ ${ }^{1}$ School of Leadership and Education Sciences, University of San Diego, USA \\ Correspondence: Viviana Alexandrowicz, School of Leadership and Education Sciences, University of San \\ Diego, USA.
}

Received: November 29, 2020

Accepted: December 17, 2020

Online Published: December 28, 2020

doi: 10.5539/elt.v14n1p107

URL: https://doi.org/10.5539/elt.v14n1p107

\begin{abstract}
The idea of offering all children and youth an education that is experiential, student centered, engaging, and relevant to life is not a new concept (Dewey, 1938; Kolb, 1981). Preparing students with the competencies, skills, and character for full participation in the $21^{\text {st }}$ century has become the vision of schools, educators, and organizations around the world (NEA, 2020; Geisinger, 2016; Trilling, B. \& Fadel, C., 2009). Changemaker teachers, staff, and administrators believe in facilitating children and youth development as citizens for the $21^{\text {st }}$ century. These educators also guide them as agents of change who empathize with others and solve real life problems for the greater good. These children and youth are what Ashoka calls "Changemakers". (Ashoka, 2020). This article explores the potential for facilitating the development of English Learners (Els) as Changemakers by using effective Second Language Acquisition (SLA) approaches in combination with experiential approaches. The intent is to contribute a theoretical framework and curriculum ideas for effective practice to help English language learners develop language, access content, and develop $21^{\text {st }}$ century skills as Changemaker attributes.
\end{abstract}

Keywords: changemaking, English learners, experiential education, community service learning, project-based learning, $21^{\text {st }}$ century skills

\section{Introduction}

\subsection{Changemaking and $21^{\text {st }}$ Century Skills}

Changemaking is not about the job you do, it's about the kind of person you are. It's a way of being in the world. It's about your attitude and your actions. It's about making everyday changes in the world, changes that make life better and changes that benefit you, your family, friends, and communities. These are changes that help you, humanity, and the planet. Changemaking involves being empathetic, thoughtful, collaborative, and taking action, leading the way to find solutions to real life problems (Ashoka, 2015). "By actively tackling a social problem, a changemaker demonstrates they are motivated to act. It is not enough to have the intention to do something good, intentions must be translated into action. This begins by having empathy for others, identifying a specific problem or opportunity to tackle, and giving one's self permission to do something about it. It doesn't stop there. Changemakers keep trying until they have made a difference" (Changemakers Learning Lab, 2016). Youth social entrepreneurs "are leading ventures that address pressing societal problems including climate change, gun reform, and social justice" (Bublitz et al., 2020) addressing UNESCO's 17 Sustainable development goals. These goals include ending poverty in all its forms everywhere, ending hunger, achieving food security, improving nutrition, promoting sustainable agriculture, ensuring healthy lives, ensuring inclusive and equitable quality education, and promoting well-being for all (2017). Young changemakers around the world are taking action to improve communities in a variety of ways, supported by teachers, their families, their community, with peers or individually. Examples include young people creating art programs for children in hospitals, providing "blessing bags with essentials" for homeless people, developing an app to help students find someone to sit at lunch in school, starting a club to help reduce plastic, creating a blog that promotes girls access to computer science, or implementing a campaign to improve empathy and connection between students, staff and custodians (Ashoka Lead Young, 2020; Martinez, L., 2016; Sunden, G., 2010; Sweeny Higginson, S., 2019).

One cannot discuss Changemaking without referring to $21^{\text {st }}$ century skills since these skills are critical for effective Changemaking. The Partnership for $21^{\text {st }}$ Century Learning believes that not only reading, writing and 
arithmetic but also learning and innovation skills, life and career skills, and information, media and technological skills are critical for citizens to master. The area of learning and innovation skills has had a great influence on education in the last decade, particularly in the areas of communication, critical thinking, collaboration and creativity. Furthermore, the P21 Framework which was developed with the input of educators, educational organizations, and business leaders, states that " 21 st century learning requires an innovative support system to engage learners through applicable skills and knowledge, appropriate technologies, and real-world connections to make learning relevant, personalized, and engaging". (Partnership for $21^{\text {st }}$ century learning, 2020).

In the U.S., a number of states have aligned the 21 st century skills framework with the Common Core Standards showing how the successful integration of both frameworks is vital to the success of students (Digital Chalkboard, 2020). The Common Core Standards (2012) lend themselves to incorporating Social Emotional Learning (SEL) theory and practice as an integral part of the curriculum. SEL is the process through which children and adults understand and manage emotions, set and achieve positive goals, feel and show empathy for others, establish and maintain positive relationships, and make responsible decisions (CASEL, 2020). Furthermore, "(SEL) can lead to positive outcomes, from increased test scores and graduation rates to improved prosocial skills that support student success in school and beyond. SEL is now considered part of a whole-child education. It is less clear what schools and teachers can do to develop these abilities" (Melnick, H. \& Martinez L., 2019).

Changemaking skills align in many ways with $21^{\text {st }}$ century skills. Researchers Rivers, Armellini, and Nie (2015) list specific Changemaker attributes that mention self-confidence, perseverance, internal locus of control, selfawareness, action orientation, creativity, critical thinking, reflection, communication, emotional and social intelligence, problem solving, leadership, value driven, and empathy. Furthermore, Ashoka's lists their main Changemaker skills as empathy, teamwork, problem solving (or changemaking), and leadership. Raza Khan \& Jakel (2017, p. 13-15) explain that the abilities of Changemakers are to: 1) Initiate things and create from nothing; 2) Serve people from different backgrounds, faiths, ages and races; 3) Imagine, dream and bring future in their hands; 4) Make decisions, choose between good and bad; 5) Innovate, create and invent new ideas that can save time and resources; 6) Alter circumstances or direction to improve their lives; 7) Express ideas, feelings, plans, and ideas, for example to highlight discrimination and injustice; 8) Inspire others with thoughts and actions; 9) Collaborate by working together toward common goals through sharing responsibility, authority and accountability; 10) Care by genuinely helping others and paying attention to their needs; 9) Appreciate others which strengthen relationships and improve team work; and, 11) Feel and empathize, walking in someone's else shoes.

One objective for this article is to answer the question "How can we use experiential approaches to help develop students as Changemakers who will take action to improve the world?" The paper integrates a review of the literature on Changemaking education for Els and provides practical examples of implementation for Community Service Learning (CSL) and Project Based Learning (PBL) approaches. The CSL and PBL curriculum and instruction presented here incorporate content and language standards, second language acquisition (SLA) strategies, and key elements of socio-culturally responsive pedagogy and funds of knowledge. One of the main goals for this publication is to contribute the literature, theory, and practice of Changemaking in $\mathrm{K}-12$ education for English learners. This educational area of study is considered pioneering work by Ashoka, a Changemaking organization in the US and world.

The subsequent sections focus on:

- The importance of developing empathy skills as the basis for helping children and youth develop into Changemakers

- A review of effective pedagogy for Els' content and language development

- The components of experiential education as a vehicle for engaging Els' in taking action to improve the world

- The elements of Community Service Learning pedagogy and implementation

- Project Based Learning's components and implementation

\section{Changemaking and the Development of Empathy}

In order to promote empathy and support SEL, teachers and administrators are able to promote a culture of empathy and respect through daily engagement in SEL based programs and activities (Sanford Harmony, 2020; Markewitz, 2020). "The empathy process in its simplest form takes place when a person's emotional response translates into a caring action" (Levine, 2005) and, it is the “....ability to understand the feelings and perspectives 
of and to use this understanding to guide our actions" (Start Empathy, 2016). Placing ourselves in the shoes of others is critical for Changemaking. A key question to ask is: What is the difference between developing $21^{\text {st }}$ century skills such as empathy and developing Changemaker skills? The answer is: Not much. The main difference is that changemaking skills are always used to take some sort of action about what we care about. This may involve interacting with others in kind and respectful ways, helping them with challenges, or leading initiatives to positively impact communities. Changemakers do something about what hurt their hearts, are aware of other people's feelings, they notice others, and are intentional about understanding others' perspectives.

Changemaker educators prepare children and youth to navigate and succeed in a world that is constantly changing and utilize pedagogies like SEL that promote socio-emotional intelligence (Goleman, 2005). They create opportunities for empowerment where students see that they can initiate change at multiple levels: in their home, school, neighborhood, city, state, country, and the global community. They teach that actions can be taken on a very small or larger scale, i.e. from developing and showing empathy for their peers during activities in the classroom or by organizing environmental campaigns in their country. They are also responsible for providing true equality by making everyone powerful, especially those who are under privileged (Start Empathy, 2016, p. 34), a category that includes many English learners.

\section{Pedagogy for Content and Language Development}

In the United States, English Learners (Els) comprise approximately 10\% of the student population (or 5 million). Spanish is the most common language with approximately $75 \%$ of the total El population (National Center for Education Statistics). An El is "a student who speaks another language besides English and has yet to demonstrate full proficiency in English on local measures of English proficiency" (Ward Singer, 2018, p. 4). English proficiency is a continuum of how well a student understands and communicates in listening, speaking, reading, and writing. The World-Class Instructional Design and Assessment English Language Proficiency Standards (WIDA, 2012) is an example of descriptors categorized into broad stages of second language acquisition that range from "Entering" level to "Bridging" level stages of proficiency. No matter what the students' proficiency in English is, US Federal and State legislation has evolved to protect their educational rights and require schools to support Els' linguistic and academic success and provide equal access to education (Ovando \& Combs, 2018).

One way to provide equal access to the curriculum is through educators understanding Els from a holistic perspective taking into consideration linguistic, academic, cognitive and socio-cultural aspects of children that may impact their schooling (Herrera \& Murphy, 2014, p. 10). Factors that may impact Els' educational achievement, include previous schooling and literacy, and language proficiency in their first and second language. Instruction and interactions with Els should be modified according to the students' levels of English proficiency. Elementary, secondary teachers and ESL teachers who support Els inside and outside their classrooms utilize Second Language Acquisition (SLA) approaches. These approaches provide Els with "instruction that is comprehensible, relevant, and motivating. ... and explicitly emphasizes language and content objectives" (Herrera \& Murphy, p. 271). Methods like the Cognitive Academic Language Learning Approach (CALLA) integrate subject matter learning, learning academic language development, learning strategies, and emphasizes learners' interactions with others grounded on socio-cultural theory model (Chamot \& Omalley, 1994). Furthermore, Sheltered Instruction (Echevarria and Graves, 2003), and Specially Designed Academic Instruction (SDAIE) (Cline and Necochea, 2003), incorporate theories of first and second language acquisition (Vygotsky, 1978; Cummins, 1999; Krashen and Terrel, 1983) to provide Els with comprehensible input to access content and continue language development.

These methods incorporate the following WIDA standards categories:

1. Sensory supports: Real-life objects (realia), manipulatives, pictures \& photographs, illustrations, diagrams, \& drawings, magazines \& newspapers, physical activities, videos \& films, broadcasts, models \& figures

2. Graphic supports: Charts, graphic organizers, tables, graphs, timelines, number lines

3. Interactive supports: In pairs or partners, in triads or small groups, in a whole group, using cooperative group structures, with the Internet (websites) or software programs, in the home language, with mentors

In addition, the WIDA Standards illustrate the importance of scaffolding language development for ELLs, and states that supports may be "using graphic organizers with a partner." Working with a partner is an interactive support because it allows for increased interaction and engagement of students. However, working with a partner 
is not always enough to scaffold language development. Educators need to organize their instruction and assessment with intention, especially considering students' roles in partner and group work, to ensure the efficacy of any support" (WIDA, 2012).

Furthermore, SLA methods also include strategies such as doing cross linguistics, hands on activities, guarded or controlled vocabulary, paraphrasing, visuals, low risk and safe environments, and primary language support. These strategies provide a way to scaffold academic concepts and language to match different levels of ability linguistically and academically. They also help students with their Cognitive Academic Language Proficiency (CALP) development which is the language learners must acquire to cope with academic demands (Cummins, 1981). Teachers play a role in supporting the learner's development and providing support structures to help students achieve their next stage or level of understanding or ability. Vygotsky (1978) believed that learning does not occur in isolation and sustained that "social interaction is the basis of learning and development". Vygotsky perceived the skills that a learner is close to mastering as being in the "Zone of Proximal Development (ZPD)" which can be achieved with guidance and encouragement from a skilled partner. According to Walqui, creating contexts for linguistic and academic learning in the ZPD occurs in part through the scaffolding of social interaction. Scaffolding is closely related to the ZPD. In fact, it is only within the ZPD that scaffolding can occur. Walqui identifies the following 6 types of instructional scaffolds (Walqui, 20016):

1. Modeling of tasks which includes showing clear examples and providing step by step instructions (e.g., taking students through the steps of finding articles on a topic on the internet).

2. Bridging by activating and capitalizing on students' prior knowledge on a topic (e.g., using an anticipatory guide with two columns about what students know about the topic, and what they want to learn).

3. Contextualizing by using manipulatives, pictures, videos, authentic objects, and real-life experiences to aid comprehension to decontextualized materials like textbooks and other academic reading (e.g., when learning about human cells students create a cell by using playdough indicating the different parts).

4. Schema building by helping students make connections and understand the different aspects of a topic (e.g., using a graphic organizer that shows important concepts that will be discussed).

5. Re-presenting text by presenting the content in different formats or by asking students to show their understanding in multiple ways (e.g., by representing an article as a play).

6. Metacognition development by teaching students learning strategies they can apply independently (e.g., summarizing texts or questioning peers).

Constructivist teachers integrate these SLA approaches and strategies with constructivist pedagogy whereby students actively construct or make their own knowledge and that reality is determined by the experiences of the learner (Vygotsky, 1978; Barron \& Darling-Hammond, 2008), Dewey, 1938; Piaget, 1970; Elliott et al., 2000). These experiences must be acknowledged and capitalized on to engage Els in their education. Effective instruction for Els needs to keep into consideration the individual and cultural background knowledge of these students. An important starting point for teachers of Els, is identifying their own teaching philosophy either as an asset or a deficit -based belief system. Deficit theories (Delpit, 1995; Garcia \& Nanez, 2011) promote "a culture of poverty" and sustain that minority students are genetically inferior or that their academic underachievement is anchored in their socio-cultural, linguistic, economic, linguistic and intellectually impoverished environments (Jensen, 1969; Ovando and Combs, 2018). An important step for Els' inclusion and participation as empowered people is for teachers knowing a child as a "whole" person and not merely as a student, taking into account the "funds of knowledge" he/she possesses outside of the classroom. For example, these funds may include knowledge of carpentry or religion beliefs and practices, (Moll, 2001). Ideally, teachers provide students with opportunities to contribute their cultural, family, and community knowledge and experiences, and are appreciated and valued as equal members in the classroom. Teachers must find ways to use student-centered approaches to integrate their students' perspectives, interests, and experiences into the learning community and activities. They must encourage students to voice their opinions, to contribute original thinking and ideas, and to show others their skills. These skills go beyond their ability to speak, read, and write in their second language in academic contexts (Quezada \& Alexandrowicz, 2019; Education Northwest, 2016; Bertani et al., 2010; Wlodkowski, R. \& Ginsberg, M., 1995).

\section{Experiential Education: Engaging in Taking Action to Improve the World}

Experiential approaches naturally incorporate the ideas and opinions of students in interactive, real world-based strategies that promote higher thinking skills where "Learning is the process whereby knowledge is created 
through the transformation of experience" (Kolb, 1984, p. 38). Experiential education involves having concrete experiences, reflective observation of the new experience, conceptualization which helps the formation of abstract concepts, and active experimentation (National Commission on Service Learning, 2002). This type of pedagogy can be integrated with content-based SLA instruction and with content standards and ELD standards to construct learning experiences that are conducive to help develop Changemakers. Community Service Learning (CSL) and Project Based Learning (PBL) are experiential approaches that have proven valuable in supporting Els not only in language development but also in academic and civic development in real world contexts.

\subsection{Community Service Learning and Els (CSL)}

CSL is a teaching pedagogy that integrates community service with academic study to encourage community engagement, enrich learning, and strengthen communities. The "learning" in service-learning results from the connections students make between their community experiences and course themes (Zivi, 1997; National Commission on Service Learning, 2002). Through their community service, students become active learners, bringing skills and information from community work and integrating them with the theory and curriculum of the classroom to produce new knowledge. The learning aspect in this type of community service is guided and facilitated with reflection being critical to the process. This is one of the main differences from performing community service alone (Mitchell, 2008). CSL integrates civic action with academic learning tied to standards. "When teachers recognize their students as agents of change, they can foster compassion and offer opportunities that not only teach fundamental skills and concepts but also result in helping build the inner character in students...supporting them in feeling they can and do make a difference" (Hansen, 2019). As a changemaking method, CSL must involve students in responding to genuine community needs and teaching them how to collaborate with community members to the extent possible in planning and implementing for addressing these needs (Celio, Dulack, \& Dymnicki, 2011). In "Changemaking CSL" there is a mutually beneficial learning and reciprocity between students and community members. In this way, students do not perceive community members as passive recipients of goodwill from others but also learn lessons from them. Some examples of community service learning include such activities as bringing toys to children in hospitals, tutoring younger children, writing cards to soldiers, collecting food to donate after a disaster, organizing clothing drives for donation to homeless organizations, raking leaves for elderly neighbors, and volunteering at animal shelters.

CSL has shown to improve academic performance and reduce achievement gaps among low income or marginalized youth (Scales \& Roehlkepartain, 2004). A study conducted with Hispanic Els who were involved in service learning programs, showed that students tended to increase their participation in class and earn better grades, became more excited about and involved in school, and demonstrated higher self-confidence (Grassi et al., 2004). When CSL is often conducted in culturally and linguistically diverse communities, knowledge of languages and cultures other than English is an asset and has the potential to benefit all students. This can be especially beneficial for groups like Hispanic second language learners, who often experience high dropout rates and low educational attainment rates in the United States (Newberger and Curry, 2000). In addition, service learning can also be a powerful experience to provide Els with authentic context to hear and practice language which is an integral part of SLA interactive methods.

\section{CSL Implementation}

This next section presents an example of implementation of CSL-based curriculum and instruction. The focus is on Changemaking, English language development, and academic and social cultural development. It integrates WIDA Standards, USA Common Core Content Standards or CCSS (2012), and USA Social Studies standards (2012). According to the social studies framework, "the study of civic ideals and practices, the central purpose of social studies, prepares learners for full participation in society. Examining civic ideals and practices across time and in diverse societies prepares learners to close the gap between present practices and the ideals upon which our democratic republic is based". Learners confront questions such as: "What is civic participation and how can I be involved?" "What is the role of the citizen in the community, in the nation, and in the world community?" How can I make a positive difference?" (National Council for the Social Studies, 2012)

In the CSL-based unit included in the article, the community service initiative is of third grade students visiting a retirement home. The Changemaking objectives are to develop empathy, awareness/understanding and respect for senior people, and bring some joy to their lives. For example, students develop empathy and appreciation for seniors and critically think about seniors' assets and life experiences; Students also develop sensitivity and awareness by putting themselves in the shoes of others. They are encouraged to be curious about people who are different from them. During the visit, students interact, communicate and play games with seniors to learn about them and bring joy to their lives. The lessons in the unit are geared to provide information about the assets and 
needs of seniors, and capitalize on students' experiences with seniors. These lessons included in the unit align with the WIDA standards and the Social Studies standards. In addition to the Changemaking/21 century skill objectives, each lesson includes language and content objectives, key vocabulary, and socio-culturally responsive pedagogy/funds of knowledge addressed. Moreover, each activity within the lesson incorporates Second Language Acquisition (SLA) strategies indicated in bold.

This CSL experience helps Els acquire language by connecting with and taking action in their community to have a positive impact on others. In the unit example below, service learning is designed and planned by the teacher but he/she also provides students with the opportunity to identify alternative ways to extend their CSL to seniors in the future. The unit reflects student-centered instruction where students bring their own rich experiences. CSL is a form of experiential education that offers Els a chance to engage, be motivated, contribute, and participate in their own learning.

\subsection{CSL Unit: Empathizing and Helping Others}

Sample WIDA Standards addressed

WIDA Standard 1 - Social and Instructional Language: English language learners communicate for social and instructional purposes within the school setting.

WIDA Standard 2 - Language of Language Arts: English language learners communicate information, ideas, and concepts necessary for academic success in the content area of language arts.

Sample Common Core Content Standards addressed: English Language Arts

CCSS.ELA-LITERACY.SL.3.1

Engage effectively in a range of collaborative discussions (one-on-one, in groups, and teacher-led) with diverse partners on grade 3 topics and texts, building on others' ideas and expressing their own clearly.

CCSS.ELA-LITERACY.SL.3.1.B

Follow agreed-upon rules for discussions (e.g., gaining the floor in respectful ways, listening to others with care, speaking one at a time about the topics and texts under discussion).

CCSS.ELA-LITERACY.SL.3.4

Report on a topic or text, tell a story, or recount an experience with appropriate facts and relevant, descriptive details, speaking clearly at an understandable pace.

Social Studies Standard addressed:

Create opportunities for learner participation in activities to strengthen the "common good," based upon careful evaluation of possible options for citizen action.

Lesson \#1: Understanding CSL and help improving the lives of seniors

Changemaking attributes/21 century skills: Empathy, appreciation for others, critical thinking.

Content objectives: Students explain community service learning in their own words. Students engage in collaborative discussions to identify characteristics of seniors, contributions they make to society, and challenges they face.

Language objectives: Students exchange information with others using verb phrases (e.g., Seniors feel pain on their knees when they walk, they like to talk to other people about their lives, etc.)

Key vocabulary includes: "Senior", "challenges", "wisdom", "contribute", "benefit", and "retirement home".

Assessments: Students provide their own definition and an example of CSL. Students write what they learned about seniors in their journal.

Socio-culturally responsive pedagogy and funds of knowledge: Students are provided with the opportunity to share experiences they have had with seniors, for example with, their grandparents (in many cultures it is common for families to include and take care of the elderly). As a result, Els are able to contribute with their "funds of knowledge".

Assessments: Students write what they learned about seniors from the discussions, video and the retirement representative in their journal.

Activity \#1: To help students understand what Community Service Learning is about, the teacher asks students "Who in this class has helped others (family, friends, strangers) with anything to make their lives better?" We engage in Community Service Learning or CSL to help people in our communities. We do this for the "common good" by helping make the lives of one person or many persons better. Community members also help us to 
learn about the real world and help us get new knowledge and skills we can use in the future. For example, they teach us about some great things about our community and we have an opportunity to talk to people who are different from us. "So, what is Community Service Learning or CSL?" "Why is the benefit of being part of CSL? After students provide definitions and contribute with ideas on positive aspects for CSL, she continues by saying "In this next unit we will help other people as a class by understanding "very old" people or "seniors" and take action to give them joy and serve their needs. Students are asked to write their own definition and an example of CSL on a piece of paper and share it with a partner. The teacher taps into students' prior knowledge by asking, "What do you know about seniors "Do you know someone who is old, for example a grandparent, what is he/she like?" "What happens to people when they age?", "What are some challenges old people may face?", "What is fun about seniors?" Students provide oral responses. The teacher uses a three-column chart to record ideas about old people/seniors with Column 1 for "General Information about Seniors", Column 2 for "Challenges Seniors face" and Column 3 for "Advantages/Contributions of Seniors. Students watch a video on "Kids meet a 101 year-old" (https://www.youtube.com/watch?v=69HgC2KghBc. The teacher asks: "What did you learn about the lady in the video?", "What are experiences seniors may have had when they were younger?" "What can seniors contribute or give to society?" The teacher adds answers to the three-column chart.

SLA strategies: 1) Teacher paraphrases to scaffold higher level words that emerge in the questions and from the discussion; 2) The discussion is student-centered since the teacher asks students to contribute their prior knowledge about seniors first; 3) A chart is used to organize prior knowledge and new knowledge based on the video; 4) The teacher uses video to build background knowledge about seniors and scaffolds by "chunking" the video into segments to discuss the language the students hear; 5) The teacher writes on a poster new vocabulary that emerges; and, 6) For lower level proficiency students, the teacher shows the video without audio and describes the images with simpler language, fewer words and at a slower pace.

Activity \#2: Invite a representative from a retirement home to explain what is a retirement home and the circumstances that drive older people to live there. Ask the representative to explain the diversity among seniors; she/he may state that some seniors are active but prefer to live in a community not to be alone, that some need extra care due to health reasons, and that seniors have had many different types of careers and jobs like being doctors and secretaries. The representative also brings ideas for two games the seniors like to play so that students can learn them. The teacher models and students practice one or two ways to introduce themselves to seniors. Students are encouraged to ask questions about the retirement home and the seniors that live there. They write what they learned about seniors in their journal.

SLA strategies: 1) The teacher may choose to paraphrase the speaker's ideas to make it comprehensible to lower level proficiency students; and, 2) The teacher discusses the examples the representative will provide about seniors prior to her/his visit to the classroom. They plan to have pictures of the retirement home and residents (or if those are unavailable, generic pictures of different types of seniors) to provide context and build students' background knowledge; and, 3) Entering/beginner Els may copy on their journal ideas about seniors from the chart.

Lesson \#2: Developing Curiosity and empathy for seniors and learning how to interview

Changemaking attributes/21 century skills: Empathy, sensitivity and self-awareness.

Content objectives: Students engage effectively in a range of collaborative discussions. They engage in thinking and designing questions to get to know seniors in their community. Students put themselves in the shoes of others and develop empathy.

Language objectives: Students develop questions for seniors using "What", "Where", "Who", "When", and "Why". They use adjectives and adverbs to add details about their experiences with seniors.

Key vocabulary includes: "favorite", "worry", "feelings", "brainstorm".

Assessments: Students create a list of questions for seniors. Students complete a drawing with bubbles sheet about what seniors feel, see, and are worried about.

Socio-culturally responsive pedagogy and funds of knowledge: Lessons and assignments encourage students to gather pertinent data from multi-cultural perspectives on existing social problems based on their individual experiences with seniors.

Activity \#1: Students brainstorm questions that they are curious about and would like to ask during the visit to the retirement home by thinking first individually and then orally sharing them as a group. Each group appoints a volunteer student to record the questions. Each group shares their questions with another group. 
SLA strategies: 1) The teacher models one or two questions students may ask such as "What is your favorite thing to do?", "In what ways can people show you that they care?" She also models how to ask follow up questions depending on the seniors' answers through role play. For example, if a senior says "Life in here is sometimes good and sometimes not so good", a follow up question could be "Can you give me a few examples of what is good and what is bad?"; 2) To make it fun and help students practice asking questions in context and make it close to real life, the teacher may wear a grey hair wig, glasses, may walk hunched over and limping to role play a senior who is answering their questions.

Activity \#2: The teacher shows a picture on the laptop projector of a senior doing an activity and asks students: "What do you think this senior is seeing around him?" "What is he feeling?" and "What is he worrying about?" The students contribute answers and discuss ideas. The teacher provides students with a blank paper and shows students a model for drawing a senior's face and drawing three bubbles where students write their responses. Students share aloud. The teacher also asks: "What do you feel about seniors?" "What do you think about seniors?" "What do you worry about seniors?" They repeat the drawing this time with their own faces and three bubbles for a response to each question.

SLA strategies: 1) The teacher uses pictures of real people to prompt student thinking and provides students with opportunities to practice writing what they brainstormed by using their own drawing; and, 2) Entering/beginner students can write using invented spelling inside the bubbles.

Lesson \#3 Learning how to play games

Changemaking attributes/21 century skills: Teamwork, problem solving, collaboration, interaction.

Content objectives: Students will be able to participate in sequentially following and articulating steps of a game in sequence.

Language objectives: Students use the vocabulary related to playing games when practicing playing with peers. They learn how to list game instructions in a sequence orally.

Key vocabulary includes: Game related words such as "player", "play the cards" "roll the dice", "taking turns", "winning chips" (vocabulary depends on the games that seniors want to play).

Assessments: Students are asked to write their own original sentences using the vocabulary related to playing the games. Students follow the games' rules and play using the new vocabulary.

Socio-culturally responsive pedagogy and funds of knowledge: Students clarify their values and make decisions about existing social problems using multi-cultural perspectives.

Activity \#1

The teacher explains words related to the games and uses a variation of the Frayer's model (teacher' toolkit, 2020) which is a graphic organizer of five squares that include the word in the middle square, a student friendly explanation, an example, a non-example (both written in meaningful sentences), and a drawing representing the word (created by each student). Students help brainstorming the examples and non-examples and copy the Frayer's pages in a personal dictionary. Students are asked to write their own original sentences using the new words.

SLA strategies: By using the Frayer's graphic organizer model, students develop understanding of key concepts and vocabulary. They also make visual connections and personal associations to the words.

Activity \#2

For a hands-on activity the teacher asks for a volunteer group to play and she re-explains each step of the game. Students interact by playing games and following rules. They practice explaining and teaching others the rules to ensure understanding.

SLA strategies: 1) The teacher models how to play the different games step by step and leaves the steps written on the board or chart; 2) Entering/beginner Els benefits from interacting and watching their peers play the game as a scaffold to understand the rules.

Lesson \#4: Field trip visit to a retirement home in the community

Changemaking attributes/21 century skills: Action-oriented, communication, empathy.

Content objectives: Students are able to engage in conversations/interviews with seniors including finding seniors' needs, and engage in playing games following instructions. 
Language objectives: Students practice introducing themselves and providing instructions for games. Language that emerges from the conversations with seniors and the games are later reviewed in class (assuming they have permission slips for all participants young and old to be video recorded).

Key vocabulary: "Player", "play your card", "roll the dice", "take turns", "winning chips".

Assessments: Students ask questions to seniors. They play the game(s) following rules effectively. They use the language related to games including adjectives, nouns, and verbs correctly.

Socio-culturally responsive pedagogy and funds of knowledge: Students clarify their values and make decisions about existing social problems using multi-cultural perspectives.

Activity \#1:

The teacher and the retirement home representative pre-plan groupings prior to the visit. Considerations for grouping are the senior and students' abilities and needs, the senior's game preference, and language spoken. For example, Spanish speaking seniors may be paired with at least one Spanish speaking student in the group. Students introduce themselves to the seniors and vice versa and students and seniors, review game rules and play.

SLA strategies: 1) The teacher creates interactive supports by placing students in strategic groups based on language proficiency; and, 2) Engaging in real life, meaningful and fun activities.

Activity\#2: In the groups, students ask questions generated in lesson \#2 that they have written on paper. Students bring notepads to take short notes about what they hear. If an El does not have the proficiency level to take notes in English, they are paired with a classmate who is able to do so. Students ask seniors if they have questions for them.

SLA strategies: All students are instructed to bring written questions brainstormed in lesson \#2 as support. Beginner Els are paired up with advanced Els or English native speakers.

Lesson \#5: Reflecting on the CSL Experience

Changemaking attributes/21 century skills: Reflective; expressing original ideas and feelings.

Content objectives: Students articulate what they learned or experienced by adding to the descriptions based on the teacher's prompts.

Language objectives: Students orally describe the activities they engaged in on the field trip to the retirement home. Students use target vocabulary to express their ideas transferred into written form.

Key vocabulary: "Action word", "person", "place", "thing", "describing word", "prepositional phrase".

Assessments: Journal writing about CSL experience and seniors.

Socio-culturally responsive pedagogy and funds of knowledge: Students use their prior knowledge to think of and add to brainstormed words (adjectives, nouns, verbs, prepositional phrases) they will use to create sentences.

Activity 1: While reviewing a video of the retirement home the teacher asks what were the different activities that students and seniors engaged in. She stops at specific points of the video and asks students to describe. For instance, students may say "there we were asking questions to a senior". The teacher uses a Sentence Patterning Chart that includes 5 columns to brainstorm "Adjectives", "Noun" (Senior), "Verbs", and "Prepositional Phrases" each in a different color. Students brainstorm words for each column that are related to "senior". The teacher models how they can create a sentence using one word from each column (e.g. "The smart senior talks to his friend at the retirement home). In groups, students write sentences using this strategy on papers or ipads.

SLA strategies: 1) Use of video to review aspects of the field trip. The teacher writes the vocabulary that emerges from the discussion and students add them to their Fryer's- based personal dictionary. The teacher and students practice using the new words by creating sentences of examples and non-examples; 2) The sentence patterning Chart provides a systematic way to review vocabulary and parts of speech with all students but in particular with Els; and, 3) Els and non-Els collaborate on writing sentences.

Activity \#2: The teacher facilitates a conversation to reflect about what students learned about the seniors and from the CSL experience. Afterwards, each student writes in his/her journal answering the following prompts: "What did you do with the senior(s)?" "What did you learn from the experience in the retirement home?" "What were your favorite parts?" What challenges did the seniors you met face?" What were the seniors' needs?" The teacher facilitates the discussion to prompt students to reflect about the CSL experience and making the life of others better or happier. She also engages them in reflecting about their experience of service learning itself by 
asking questions such as "What was the easiest part of engaging in CSL experience?" "What was the hardest part of engaging in CSL experience?" "How did this experience make you feel and why?"

SLA strategies: El students at the lower proficiency levels in the writing domain are provided with sentence frames such as "I learned that the senior I interviewed or played with ..." and "Challenges or hard thing for seniors are...", "The hard part of the experience was...", and "The greatest part of the experience was..."

Lesson \#6 Extended activities for CSL and seniors

Changemaking attributes/21 century skills development: Problem-solving, leadership; value driven, collaboration, responsibility, authority and accountability.

Content Objectives: In groups, students select a way they give back to seniors or help create awareness about and empathy for them.

Language Objectives: Students identify and compose lists of what they will need to organize a drive to contribute to the seniors in the retirement community they visited.

Key vocabulary: "Initiative", "resources", "materials", "involved", "challenges".

Assessments: Students carry their new CSL initiative and reflect on what they learned.

Socio-culturally responsive pedagogy and funds of knowledge: Students share their stories orally or in writing. Student work (ideas) are displayed on the wall. Students clarify their values and make decisions about existing social problems using multi-cultural perspectives; Students take their brainstormed actions to help resolve social problems.

Activity: In small groups students brainstorm how they can extend their CSL into the future by contributing to seniors' lives. For example, students may choose to organize a drive to collect magazines, games, or other items seniors may have expressed need for. They may also make picture frames to give them to seniors as gifts. The teacher creates a chart for planning including four columns: Column 1 "What is the initiative about?" Column 2 "What resources do we need to carry it out?" (e.g. materials); Column 3 "Who needs to be involved?" (people that will help us); and, Column 4 "What are some challenges we may face planning or implementing a CSL initiative?". The teacher guides students in carrying out their CSL initiatives in future units, including reflecting on what they learned.

SLA strategies: 1) Chart for scaffolding the student's thinking process about what will be their extension CSL activity; 2) The teacher paraphrases vocabulary including "drive", "contributing", "resources", "carry out", and "implementing".

\section{Els and Project-Based Learning}

Project Based Learning (PBL) is a teaching method in which students gain knowledge and skills by working for an extended period of time to investigate and respond to an authentic, engaging, complex question, problem, or challenge. In PBL, the project is the vehicle for teaching the knowledge and skills that students need to learn and is aligned to curriculum and instruction frameworks. PBL also includes addressing a challenging problem or question, thinking critically, problem solving, collaborating, using student voice, reflecting, and a creating a public product (Buck Institute, 2020). Research on PBL as a teaching model that facilitates learning has shown that is can greatly improve student learning, problem solving, and analytical skills for all learners. It also has shown that students develop a deeper understanding of subject matter (Blumenfeld et al., 1991; Hall \& Miro, 2016). Like Community Service Learning, PBL Learning has great potential for engaging Els to access content and language via authentic tasks. A study of PBL and Els, indicated that PBL provided significant benefits to ELs in the areas of academic engagement, mindset, confidence, sense of belonging, personal accountability to learning, and problem-solving skills (Nunez, 2018).

PBL uses design thinking models that are based on a process that evolves in different stages. For example, models focus on children as designers who begin empathizing with others that are affected by a problem. Also, many of these models focus on final products that engage students to take action for social causes and bring about positive change. Examples of projects include student initiatives on stopping food waste, protecting bees, supporting refugees, developing awareness for climate change, and reducing pollution (DFC, 2020; Ashoka, 2020). Moreover, projects can be carried out in local and global contexts, including homes, neighborhoods, communities, cities, states, countries and beyond. The Design for Change organization (DFC), is a global organization that promotes social causes and publishes project design toolkits for 20 countries (DFC, 2020). Their model includes four steps for developing projects: 1) Feel (build empathy); 2) Imagine (brainstorm ideas); 3) Do (implement solutions); and, 4) Share (Inspire others). In the example included in this article, the student 
population is comprised by Els and native speakers of English. The project incorporates second language acquisition SLA strategies to scaffold Els' comprehension and participation at different levels of language proficiency (strategies are highlighted in boldface). During this PBL, students have equal opportunity to participate in providing ideas for causes or problems they care about and "hurt their hearts". They engage in collaborative discussions about "why" their individual issue is important, and participate in planning and implementation activities that focus on: 1) Thinking from their hearts, identifying and voting for an issue; 2) Visualizing change and solutions for the issue that the group selected; 3) Making change happen by designing and implementing a solution; and, 4) Sharing their story.

\subsection{PBL Implementation}

Project: Solving Issues that "Hurt our Hearts"

Changemaking/21 century skills: Communication, critical thinking, collaboration and creativity, action orientation, critical thinking, reflective, emotional and social intelligence, problem solving, leadership, value driven, and empathy.

\section{Sample Common Core standards addressed:}

\section{CCSS.ELA-LITERACY.SL.3.1}

Engage effectively in a range of collaborative discussions (one-on-one, in groups, and teacher-led) with diverse partners on grade 3 topics and texts, building on others' ideas and expressing their own clearly.

CCSS.ELA-LITERACY.SL.3.1.B

Follow agreed-upon rules for discussions (e.g., gaining the floor in respectful ways, listening to others with care, speaking one at a time about the topics and texts under discussion).

CCSS.ELA-LITERACY.SL.3.4

Report on a topic or text, tell a story, or recount an experience with appropriate facts and relevant, descriptive details, speaking clearly at an understandable pace.

Sample WIDA Standards addressed:

WIDA Standard 1 - Social and Instructional Language: English language learners communicate for social and instructional purposes within the school setting.

WIDA Standard 2 - Language of Language Arts: English language learners communicate information, ideas, and concepts necessary for academic success in the content area of language arts.

Sample Social studies standards addressed:

Create opportunities for learner participation in activities to strengthen the "common good," based upon careful evaluation of possible options for citizen action.

Content objectives: Students identify issues that affect their communities, and plan and implement solutions to solve these issues.

Language objectives: Students use oral and written language to develop questions, summarize research on their topic, negotiate why their issue is important, and write a letter to stakeholders.

Sample Vocabulary: "Changemakers", "impact", "transform", "initiatives", "positive impact".

Assessments: Students draw a Changemaker, and write their own definition and examples of projects. Students write in their PBL journal, in the findings from research, statement of the problem, and potential solutions sections. Students disseminate/present their information through media following a specific structure and required content for what they did in each step of the PBL.

Socio-culturally responsive pedagogy and funds of knowledge: This PBL not only allows for meeting Els at their proficiency level in purposeful and collaborative contexts, but also encourages voice and choice for Els. In this example, students are able to dialogue about their prior knowledge about littering. Els may be provided the option of explaining their ideas orally or in writing about what they know on the topic in their native language. In this way, the teacher validates Els' knowledge and experiences by providing them with a chance to contribute their "funds of knowledge" to the learning community. As a result, Els are viewed from an asset-based perspective on what they are able to do as opposed as on what they can't do. They are able to equally participate and collaborate with their classmates. 
Step 1: Feel or think from your heart

To inspire and spark all of her students' interest, the teacher provides a list or shows pictures and short descriptions of projects developed by other students found at https://www.designforchange.us/pages/stories. In addition, she reads stories about Changemakers (Martinez, 2016) and kids who are changing the world (Higginson, 2019). She explains that some of these young changemakers worked alone and/or in collaboration with other kids and adults. She introduces the idea of helping improve or "making the lives of other people better". After each story, the class discusses what each changemaker project was, the challenges they face, and what are other ways they could have solved the problems. Students are asked to draw a Changemaker, write their own definition, and examples of projects. In this stage, the teacher encourages students to reflect about things that bother them.

The teacher explains the steps they will take to carry their project in the stages of "feel", "imagine", "do", and "share" and the actions students must take in each stage. Students are placed in mixed groups of Els and native English speakers and collaborate on identifying a cause they will like to focus on. They begin by each student adding his/her own issue to a chart. The students vote by using posted notes for their first and second option and decide on the one that obtains the most votes. For the purposes of this article, the assumption is that one group of students has chosen the topic of littering in their community and therefore the instructional strategies suggested here are based on that topic. Students write a 3-sentence explanation of the problem in their PBL journal, section \#1 "Statement of the Problem".

As part of this first step in the design thinking process, students research their problem online and/or read articles about littering in communities and cities, including common sources for the problem and solutions. They may also watch videos about the topic of littering. Students talk to people who are involved in and affected by the situation. These community stakeholders may include members of the city council and business owners. The teacher guides students in brainstorming questions to capture the potential interviewees' perspectives on what has already been done to solve the problem and their suggestions for solving the issue. Students write their research findings in their PBL journal, section \#2 "Findings from Research".

SLA strategies: 1) The teacher shows a model of her own changemaker drawing, definition and examples of projects. Entering/beginner Els may copy the sentences but create their own drawing. 2) The teacher identifies vocabulary in the readings about young changemakers that may be new to all students and language that may present challenges to Els (e.g. garbage, plastic, debris, contaminated, pollute, destroy). She frontloads the vocabulary and creates a vocabulary chart explaining the words and using them in meaningful sentences 3 ) Lower proficiency Els can represent their issue by drawing and letting their peers guess what the issue is about. They may use Google translate to clarify for their peers in case that they are not able to identify the issue; 4) The teacher provides sentence frames to scaffold the language Els need to negotiate and explain why their specific issues should be considered. These may include "I think this issue is important because...." and "another interesting topic would be ...because..." 5) Els may face the challenge of readings on littering that may be well above their levels of English proficiency for decoding or encoding text. One approach to solve this problem is to ask students who are at advanced levels of reading and writing proficiency to represent the knowledge by writing short summaries and share them orally with El peers. This in turn reduces the new vocabulary that Els must understand and Els add the new vocabulary words into their Fryer's based personal dictionary (mentioned in the previous CSL section) with their teacher's assistance.

\section{Step 2: Imagine or visualize change}

In this stage, students brainstorm ideas for solutions to the problem to imagine change. The teacher emphasizes that all ideas are good ideas and that they can build on the ideas of others by using the word "and" instead of "but". She models this positive language by using the sentence frame such as "I like your idea and how about doing this idea?" She encourages students to develop ideas that are easy to replicate, are long lasting, and impact a large number of people. All groups of students use a graphic organizer to record their ideas for addressing their issue and potential solutions for littering. These solutions may include organizing a clean-up day in the neighborhood, raising money to buy more regular trash and recycling cans, creating a poster campaign for reducing littering, or creating a video about the sources for littering and possible solutions. Students vote for their first and second favorite ideas for a solution. Students solutions in their PBL journal, section \#3 "Potential Solutions".

SLA strategies: 1) The teacher models how to start filling the graphic organizer using one of her own PBL ideas, 2) Groups are asked to find a picture representing their topic, in this case, of littering on the streets, parks, driveways, etc. in the community. They can also find pictures of items that are considered litter (e.g. wrappers, 
empty cans); and, 3) For beginner Els, the teacher provides basic vocabulary that is emerging in the discussion such as "throw", "pick up", "bottle", "dirty", "plastic", and "garbage". The teacher scaffolds with gestures and pointing at the specific items in the pictures.

Step 3: Do

Once groups have decided on their idea for solving the problem, they must identify what they will need to carry out their project. To help them capture these needs, the teacher provides a concept chart with three columns stating the steps. Column 1 is for "Steps to Carry out the project", Column 2 for "Budget or Money Needed", Column 3 for "People and Resources Needed", and Column 4 for "Timelines for the different steps in the project". Groups complete their charts with ideas for each column. For example, for the project to solve littering in the community, and after talking to community members and researching the issue, students may decide that buying and placing more trash cans in strategic places is a key solution. For this project, examples of responses for Column 1 may be: a) Accessing ipads to take pictures of litter in the community; 2) Go on a walk through the neighborhood to take pictures, talk to community members and pick up litter; and, b) Writing a persuasive letter to the city mayor. In this letter students outline the problem, state the reason for identifying the specific solution, and present the budget needed to acquire and place each trash can. The letter may include scanned pictures of places in the community with larger amounts of litter. Examples for Column 2 are: a) Calling the city sanitation's department to investigate the cost of placing and cleaning the trash cans; and, b) Creating a budget for the number of trash students believe they need. An example for Column 3 is: a) People and resources they need which may include three or more parents/guardians as volunteers to accompany the students around the community. An example for Column 4 may include the time needed to complete steps \#1, \#2, \& \#3. After completing these steps and assuming that students get a positive response from the mayor's office, they follow the mayor's office instructions for the next steps in the process. In the instance that the project does not get supported by the main stakeholder (the city's Mayor), the teacher encourages groups to brainstorm alternative ways to plan and implement their idea. For instance, the students may approach business owners to finance their project.

SLA strategies: 1) The teacher provides examples for each column in the concept chart; 2) She taps into prior knowledge about what is persuasive writing and provides a mentor text and a format to help identify the key components of persuasive writing (e.g. introduction, reasons, conclusion); and, 3) She explains new vocabulary such as "sanitation department" and "alternative ways".

\section{Step 4: Share}

In this stage, students share their completed Changemaking experience to inspire others via different media. These media may include presentations in their school via assemblies, during parent meetings, or posting a short article in community newsletters. They may also consider TV channels, YouTube and other social media. They can share it as a photo story, video story, or a written one. Each group discusses how they would like to share, and critically think about pros and cons of presenting in the different formats and/or media. They fill in a chart with four horizontal columns for the different types of sharing formats and two vertical columns for "advantages" and "disadvantages". After the groups have made a decision, the teacher provides students with a graphic organizer that includes the steps to prepare their sharing project. For example, for a presentation during their school's assembly, students may select pictures taken of littering in community places and develop a presentation on their ipads. For the writing part of their presentation, the teacher provides a basic structure that includes what they did during the "Feel" step, the "Imagine step", and the "Do" step. Each student in the group is required to play a role in the presentation. For example, entering/beginner Els may choose to select the pictures for the presentation. They can also translate some words into their native language and write captions in two languages.

SLA strategies: 1) The teacher provides the different options students have to disseminate their projects on cards that contain the names and graphic representations of each media format. In this way, beginner Els are able to select an option without having to speak; 2) Students are also able to translate their thoughts about advantages and disadvantages on Google translate and add to the list; 3) The teacher frontloads vocabulary such as "inspire" and "assembly".

\section{Conclusion}

One recommendation for future research is collecting data on Els' acquisition of $21^{\text {st }}$ century skills/changemaker attributes as well as content or language standard-based knowledge and skills particularly when engaging in experiential education. Experiential learning offers all students with opportunities to connect their learning to the real world and engage in social causes that help improve and enrich their lives and the lives of others. English 
learners in particular, benefit from participating in Community Service Learning and Project Based Learning through interacting and collaborating with peers and community members. The experiences presented in this article promote the development of $21^{\text {st }}$ century skills such as empathy for seniors and critical thinking about community problems. Els are able to fully participate in discussions and planning of experiences as a result of intentional scaffolding for language development by teachers. In an era where more educators believe in student-centered and constructivist approaches, Els have more opportunities to learn content and language in meaningful contexts and for real life purposes. They now have an opportunity to be heard, be validated individually and culturally, and be part of solving word problems and becoming young Changemakers.

\section{References}

Alden Rivers, B., Armellini, A., \& Nie, M. (2015). Embedding social innovation and social impact across the disciplines: The Changemaker Attributes. Higher Education, Skills and Work-Based Learning, 5(3), 242-257. https://doi.org/10.1108/HESWBL-10-2014-0051

Ashoka Lead Young. (2020). Retrieved from https://www.ashoka.org/en-us/collection/lead-young

Ashoka. (2015). Every young person becoming a changemaker: Strategy. Internal document.

Ashoka. Retrieved from https://ashoka.org

Bellanca, J. A. (Eds.). (2010). $21^{\text {st }}$ century skills: Rethinking how students learn. Indiana: Solutions Tree Press.

Bertani, T. A., Carroll, L., Castle, M. H., Davies, K. E., Hurley, A. M., Joos, T. L., ... Valenti, M. (2010). Culturally Responsive Classrooms.

Bloom, B. S., Engelhart, M. D., Furst, E. J., Hill, W. H., \& Krathwohl, D. R. (1956). Taxonomy of educational objectives: the classification of educational goals: handbook I: cognitive domain (No. 373.19 C734t). New York, US: D. Mckay.

Celio, C. L., Durlak, J., \& Dymnicki, A. (2011). A meta-analysis of the impact of service learning on students. Journal of Experiential Education, 34(2), 164-181. https://doi.org/10.1177/105382591103400205

Chamot, A. U., \& O'Malley, J. M. (1994). The CALLA handbook: Implementing the cognitive academic language approach. New York: Addison-Wesley Publishing Company.

Changemakers Learning Lab. (2016). More than simply "doing good": A definition of a changemaker. Retrieved from

https://www.evansville.edu/changemaker/downloads/more-than-simply-doing-good-defining-changemaker. pdf

Cline, Z., \& Necochea, J. (2009). Specially designed academic instruction in English (SDAIE): More than just good instruction. Multicultural Perspectives, 5(1), 18-24. https://doi.org/10.1207/S15327892MCP0501_4

Common Core Standards (CCSS) Initiative. (2012). Retrieved from https://www.corestandards.org/

Cummins, J. (1999). BICS and CALP: Clarifying the distinction. ERIC document.

Delpit, L. (2006). Other people's children: Cultural conflict in the classroom. The New Press.

Dewey, J. (1938). Experience and education. New York: Macmillan.

Digital Chalkboard. (2020). Where California educators collaborate. Retrieved from https://www.mydigitalchalkboard.org/portal/default/Content/Viewer/Content?action=2\&scId=306588\&sciI $\mathrm{d}=17934$

Durlak, J. A., Dymnicki, A. B., Taylor, R. D., Weissberg, R. P., Schellinger, K. B., Dubois, D., ... O’Brien, M. U. (2007). Collaborative for Academic, Social, and Emotional Learning (CASEL).

Echavarria, J. et al. (2007). Making content comprehensible for English language learners: The SIOP model. Boston, MA: Allyn and Bacon.

Education Northwest. (2016). Culturally responsive teaching: A guide to evidence-based practices for teaching all students equitably. Retrieved from https://educationnorthwest.org/resources/culturally-responsive-teaching-guide-evidence-based-practices-tea ching-all-students

Elliott, S. N., Kratochwill, T. R., Littlefield Cook, J., \& Travers, J. (2000). Educational psychology: Effective teaching, effective learning (3rd ed.). Boston, MA: McGraw-Hill College. 
G. L. A. D. (Guided Language Acquisition Design). Retrieved from https://www.ahisd.net/common/pages/UserFile.aspx?fileId=5074816

García, E. E., \& Náñez Sr, J. E. (2011). Bilingualism and cognition: Informing research, pedagogy, and policy. American Psychological Association. https://doi.org/10.1037/12324-000

Geisinger, K. F. (2016). 21st Century Skills: What Are They and How Do We Assess Them? Applied Measurement in Education, 29(4), 245-249. https://doi.org/10.1080/08957347.2016.1209207

Goleman, D. (2006). Emotional intelligence. New York: Bantam Dell.

Grassi, E., Hanley, D., \& Liston, D. (2004). Service learning: An innovative approach for English learners. Journal of Experiential Education, 27(1), 87-110. https://doi.org/10.1177/105382590402700107

Hansen, C. B. (2019). The Heart and Science of Teaching: Transformative Applications That Integrate Academic and Social-Emotional Learning. Teachers College Press.

Herrera, S. G., \& Murry, K. G. (2006). Mastering ESL and Bilingual Methods: Differentiated Instruction for Culturally and Linguistically Diverse (CLD) Students. Education Review.

Jensen, A. R. (1969). How much can we boost IQ and scholastic achievement? Harvard Educational Review, 39(1), 1-123. https://doi.org/10.17763/haer.39.1.13u15956627424k7

Kolb, D. A. (1984). Experiential learning: Experience as the source of learning and development (Vol. 1). Englewood Cliffs, NJ: Prentice-Hall.

Krashen, S. D., \& Terrell, T. D. (1983). The natural approach: Language acquisition in the classroom. Englewood Cliffs, NJ: Prentice Hall.

Lemke, C. (2002). enGauge 21 st Century Skills: Digital Literacies for a Digital Age.

Lemke, C. (2003). $21^{\text {st }}$ century skills for 21 s century learners. Naperville: North Central Educational Lab.

Levine, D. (2005). Teaching empathy: A blueprint for caring, compassion, and community. Indiana: Solution Tree.

Levine, D. A. (2013). Teaching empathy: A blueprint for caring, compassion, and community. Solution Tree Press.

Markowitz, N. L., \& Bouffard, S. M. (2020). Teaching with a Social, Emotional, and Cultural Lens: A Framework for Educators and Teacher Educators. Harvard Education Press, Cambridge, MA.

Martinez, L. (2016). Change Makers. Mexico: Pearson Education.

McLeod, S. A. (2019). What is the zone of proximal development? Simply psychology. Retrieved from https://www.simplypsychology.org/Zone-of-Proximal-Development.html

Melnick, H., \& Martinez, L. (2019). Preparing teachers to support social and emotional learning: A case study of San Jose State University and Lakewood Elementary School. Learning Policy Institute. Retrieved from https://www.learningpolicyinstitute.org

Mitchell, T. D. (2008). Traditional vs. critical service-learning: Engaging the literature to differentiate two models. Michigan Journal of Community Service Learning, 14(2), 50-65.

Moll, L. C., Amanti, C., Neff, D., \& Gonzalez, N. (1992). Funds of knowledge for teaching: Using a qualitative approach to connect homes and classrooms. Theory into practice, 31(2), 132-141. https://doi.org/10.1080/00405849209543534

National Center for Education Statistics. (2019). English learners in public schools. Retrieved from https://nces.ed.gov/programs/coe/indicator_cgf.asp

National Commission on Service Learning. (2002). Learning in Deed: the power of service learning for American schools. Retrieved from https://ed253jcu.pbworks.com/f/LearningDeedServiceLearning_American+Schools.PDF

National Council for the Social Studies. (2002). National curriculum standards for social studies: Chapter 2-The themes of social studies, (10) Civic Ideals and Practice. Retrieved from https://hawaiiteacherstandardsboard.org/content/wp-content/uploads/2004-NCSS-Soc-Standards.pdf

National Council for the Social Studies. (2010). National Curriculum Standards for the Social Studies: A framework for teaching, learning, and assessment. Retrieved from https://www.socialstudies.org/standards/national-curriculum-standards-social-studies 
National Education Association. (2020). Partnership for $21^{\text {st }}$ century skills. Retrieved from https://www.nea.org/home/34888.htm

National Science Teaching Association. (2020). Next generation science standards. Retrieved from https://www.nsta.org/science-standards

Newburger, E. C., \& Curry, A. (2000). Educational attainment in the United States: Population characteristics. Washington, DC: U.S. Department of Commerce, Economics and Statistics Administration.

Ovando, C. J., \& Combs, M. C. (2018). Bilingual and ESL classrooms: Teaching in multicultural contexts. Maryland: Rowman and Littlefield, 65-78.

Partnership for $21^{\text {st }}$ Century Learning. (2020). Framework for $21^{\text {st }}$ century learning. Retrieved from https://static.battelleforkids.org/documents/p21/P21_framework_0816_2pgs.pdf

Pellegrino, J. W., \& Hilton, ML. (Editors). (2012). Education for life and work: Developing transferable knowledge and skills in the $21^{\text {st }}$ century. Washington, DC: National Research Council. Retrieved from https://www.nap.edu/catalog.php?record_id=13398

Piaget, J. (1970). Science of education and the psychology of the child. New York: Viking.

Quezada, R., \& Alexandrowicz, V. (2019). Developing Culturally Proficient Teachers for Dual-Language Classrooms. Theory Into Practice, 58(2), 185-193. https://doi.org/10.1080/00405841.2019.1569398

Raza Khan, A., \& Jakel, T. (2017). Yes! Youth-led Changemaking: A game changer in the field of youth development. Berlin, Germany: YES Founders Foundation gUG.

Reimers, F., \& Chung, C. (Editors). (2016). Teaching and learning for the $21^{\text {st }}$ century. Cambridge, MA: Harvard Education Press.

Sanford Harmony. (2020). Retrieved from https://www.sanfordharmony.org/teachers/

Scales, P. C., \& Roehlkepartain, E. C. (2004). Community service and service learning in U.S. public schools, 2004: Findings from a national survey. St. Paul, MN: National Youth Leadership Council.

Start Empathy. (2016). Changemakers: Educating with a purpose. Arlington, VA: Ashoka.

Sunden, G. (2010). Real kids, real stories, real change. Minnesota: Free Spirit Publishing.

Sweeny Higginson, S. (2019). You should meet kids changing the world. New York: Simon and Schuster.

Teacher's toolkit. (2020). Frayer's model. Retrieved from https://www.theteachertoolkit.com/index.php/tool/frayer-model

Trilling, B., \& Fadel, C. (2009). $21^{\text {st }}$ century skills: Learning for life in our times. San Francisco: Jossey Bass.

UNESCO. UNESCO and sustainable and development goals. Retrieved from https://en.unesco.org/sustainabledevelopmentgoals

Vygotsky, L. S. (1962). Thought and language. Cambridge, MA: Harvard University Press. https://doi.org/10.1037/11193-000

Walki, A. (2006). Scaffolding instruction for English language learners: A conceptual framework. The International Journal of Bilingual Education and Bilingualism. https://doi.org/10.1080/13670050608668639

WIDA. (2012). The English language development standards (pp. 11). Retrieved from https://wida.wisc.edu/sites/default/files/resource/2012-ELD-Standards.pdf

Wlodkowski, R. J., \& Ginsberg, M. B. (1995). A framework for culturally responsive teaching. Educational Leadership, 53(1), 17-21.

World Economic Forum. (2014). New vision for education report. Retrieved from https://www3.weforum.org/doc/WEFUSA_NewVisionforEducation_Report2015.PDF

Zivi, K. (1997). Examining pedagogy in the service-learning classroom: Reflections on integrating service-learning into the curriculum. Experiencing citizenship: Concept and models for service-learning in political science. American Association for Higher Education.

\section{Copyrights}

Copyright for this article is retained by the author(s), with first publication rights granted to the journal.

This is an open-access article distributed under the terms and conditions of the Creative Commons Attribution license (http://creativecommons.org/licenses/by/4.0/). 